\title{
Message from the Editor: Looking Back at 2021
}

\author{
Almira R. Bayanova ${ }^{1 *}$ (ib) \\ ${ }^{1}$ Kazan Federal University, Kazan, RUSSIA \\ *Corresponding Author: ijese@ijese.com \\ Citation: Bayanova, A. R. (2022). Message from the Editor: Looking Back at 2021. Interdisciplinary Journal of Environmental and Science Education, \\ 18(1), e2265. https://doi.org/10.21601/ijese/11504
}

Past years have brought many challenges to everyone and all institutions across the globe. 2021 was a challenging but rewarding year for Interdisciplinary Journal of Environmental and Science Education (IJESE). This year, we are pleased to receive great news:

\section{IJESE is now indexed in Scopus}

(https://www.scopus.com/sourceid/21101053573).

SCOPUS is one of the largest abstract and citation database of scientific journals in the world. We would like to express our heartfelt thanks to all our reviewers and editors whose valuable contributions, evaluations, and insights have played a very important role in this accomplishment. We also would like to thank to all our authors who have submitted their manuscripts to our journal for scientific evaluation.

IJESE continues to be the destination of numerous manuscript submissions and a source of highly cited articles. IJESE received 95 manuscripts from January 1, 2021 to December 31, 2021. Out of these 95 manuscripts, 14 manuscripts were accepted for publication, 70 manuscripts were rejected. 11 manuscripts are still under review. Acceptance rates of past 4 years are shown in Figure 1. The success of IJESE is due in large part to its highly selective editorial process, which is evident from Figure 1, and its dedication to publish exclusively top-quality scientific articles.

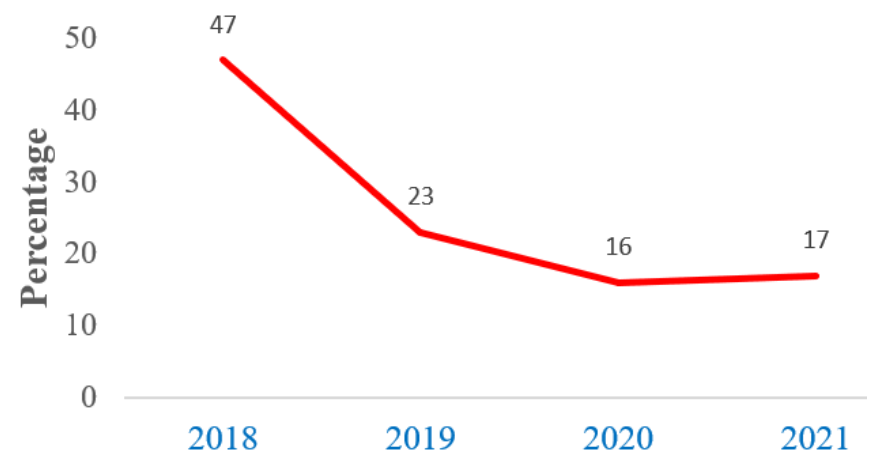

Figure 1. Acceptance rates
The breakdown of the authors by country for articles accepted in 2021 is shown in Figure 2. As can be seen from the figure, our authors are located across various geographical locations and different continents, mostly from USA, followed by Israel, New Zealand, Estonia, Ireland, Argentina, Germany, and Philippines. Managing the review processes of manuscripts submitted to the journal involves coordinated efforts of editors and reviewers. Their substantive comments and positive feedbacks ensure the validity and quality of the published articles. We feel fortunate to be a part of this distinguished team who consists of editorial board members and reviewers from all continents, mostly from USA, followed by Canada, UK, New Zealand, Brazil, Germany, India, Turkey, Greece, Cyprus, Malaysia, and Taiwan.

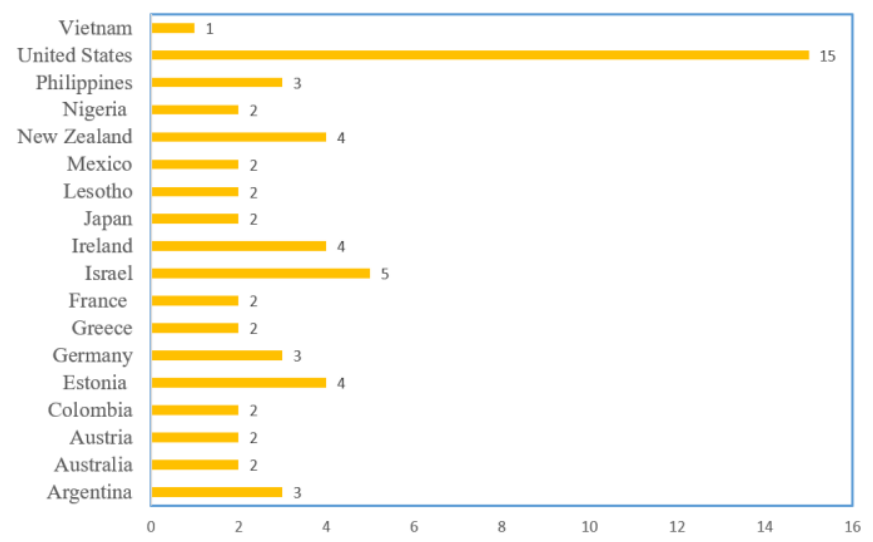

Figure 2. Breakdown of authors by country

As a natural consequence of our commitment to publish articles after a rigorous peer-review process and make them openly accessible to general audience, IJESE continues to be considered a trusted source in the field of science and environmental education. Articles published in the journal achieve wide distribution, high impact and visibility. In 2021, articles published in the journal enjoyed about a total of 43,000 views and 35,000 downloads. Hereby, we would like to congratulate the authors of 5 most cited articles in the journal (See Table 1). 
Table 1. Most cited articles

\begin{tabular}{|c|c|c|c|c|c|c|c|}
\hline Author & Article & Year & Volume & Issue & Page & WoS & SCOPUS \\
\hline $\begin{array}{l}\text { Holbrook, J. and } \\
\text { Rannikemae, M. }\end{array}$ & The meaning of scientific literacy & 2009 & 4 & 3 & $275-288$ & 138 & 179 \\
\hline Mansour, N. & $\begin{array}{c}\text { Science teachers' beliefs and practices: Issues, implications } \\
\text { and research agenda }\end{array}$ & 2009 & 4 & 1 & $25-48$ & 124 & 148 \\
\hline $\begin{array}{l}\text { Behrendt, M. and } \\
\text { Franklin, T. }\end{array}$ & $\begin{array}{c}\text { A review of research on school field trips and their value in } \\
\text { education }\end{array}$ & 2014 & 9 & & $235-245$ & 92 & 126 \\
\hline Christidou, V. & $\begin{array}{c}\text { Interest, Attitudes and Images Related to Science: } \\
\text { Combining Students' Voices with the Voices of School } \\
\text { Science, Teachers, and Popular Science }\end{array}$ & 2011 & 6 & 2 & $141-159$ & 88 & 98 \\
\hline Cakir, M. & $\begin{array}{l}\text { Constructivist Approaches to Learning in Science and Their } \\
\text { Implications for Science Pedagogy: A Literature Review }\end{array}$ & 2008 & 3 & 4 & 193-206 & 70 & 92 \\
\hline
\end{tabular}

As the editors, we are always open to new special issue proposals. We believe that special issues serve as unique means to promote high-quality targeted scientific articles of high impact. We would like to present an opportunity for researchers to contribute to a special issue that provides an excellent occasion to examine and review a particular theme, develop new approaches, and encourage new lines of research. We encourage all researchers to submit their special issue proposals that falls within the aims and scope of the journal to the editorial office at ijese@ijese.com. The quality of each special issue proposal will be evaluated based on the expertise of the leading editor, possible authors, reviewers, guest editors and contribution of the proposed topic to the literature.
IJESE is proudly partnered with Sustainable Globe Project to publish selected articles of Sustainable Globe Conference 2022 in a special issue in IJESE. In this special issue, selected papers from the conference will be eligible for further review and be published in the journal. Sustainable Globe Conference 2021 was organized by Martin Luther University HalleWittenberg, Germany. For more information, please refer to: https://sustainableglobal.net/about-conference/.

The presence and active involvement of the scientific community have been a real motivation and support to bring before you such significant and cutting-edge content. We kindly invite you to enjoy all published articles and consider IJESE as the destination for your next manuscript submission. 